\title{
Arcybiskup Józef Życiński - promotor mediatyzacji Kościoła
}

Ks. DR hab. Józef KLOCh, PROF. UKSW

Uniwersytet Kardynała Stefana Wyszyńskiego w Warszawie

Mediatyzacja to dwukierunkowy proces, w którym media wyłaniają się jako niezależna instytucja z własną logiką działania, do której muszą się dostosować pozostałe podmioty społeczne. Jednocześnie w procesie tym media stają się także częścią danych instytucji, takich jak rodzina polityka, religia czy Kościół ${ }^{1}$. W podmiotach pełnią wiodącą rolę liderzy, wybitne osobowości, teoretycy i praktycy czy uczeni. Gdy jako pierwsi wprowadzają media do danej instytucji - stają się pionierami ich zastosowań w obrębie danej jednostki.

1 O mediatyzacji w odniesieniu do religii i związanych z nią instytucji: S. Hjarvard, The Mediatization of Religion. A Theory of the Media as an Agent of Religious Change. Paper presented to the 5 th International Conference on Media, Religion and Culture, Sigtuna, Sweden, 6-9 July, 2006, http://oldintranet.oikosnet-europe.eu/Archives/Meetings/Annual_Conferences/Sigtuna_2006/Download/The\%2omediatization\%20 of\%2oreligion.pdf [dostęp: 02.05.2016]; tenże, Mediatization and the changing authority of religion, "Media, Culture \& Society" 38 (2016) 1, s. $8-17$. 
Wspierając następnie ich obecność w danym kręgu bądź wychodząc ku mediom, stają się promotorami mediatyzacji.

W przypadku Kościoła w Polsce znaczny wkład w propagowanie mediów, ale i w obecność w mediach ma m.in. kilku duchownych - Jan Chrapek², Tadeusz Pieronek oraz Józef Życiński. Byli oni ludźmi nauki, wykładowcami, zwolennikami obecności Kościoła w mediach i powoływania do istnienia mediów w kręgu Kościoła, a w Polsce pionierami w odniesieniu do siebie obydwu tych rzeczywistości. Wszyscy trzej z czasem zostali też biskupami; wówczas jeszcze bardziej efektywnie mogli kształtować odniesienia Kościółmedia lub promować media w Kościele i odwrotnie.

Niniejszy artykuł dotyczy roli, jaką odegrał w mediatyzacji Kościoła Józef Życiński - duchowny, profesor filozofii, a później biskup. W pierwszym rzędzie przeanalizowany zostanie na podstawie źródeł jego aktywny udział w powoływaniu do życia różnych podmiotów medialnych w zakresie prasy, książki, radia, telewizji i Internetu. Przywołane zostaną fakty i dokumenty świadczące o jego wkładzie w zapoczątkowanie aktywności Kościoła w poszczególnych gałęziach mediów lub w intensyfikowanie tejże.

Druga część artykułu dotyczyć będzie mediatyzacji, jaka przebiegała w Kościele w Polsce przy czynnym udziale bp. Józefa Życińskiego. Proces ten, jak zostało to już wspomniane powyżej, jest dwustronny. Stąd postawione zostaną

2 Por. Kościót a środki społecznego przekazu, red. J. Chrapek, Warszawa 1990. 
pytania o media, które przy współudziale ordynariusza tarnowskiego stały się częścią Kościoła w Polsce, ale i przywołane będzie zagadnienie mediów jako niezależnych instytucji, do których Kościół się dostosowywał. W podsumowaniu zaś zwrócona zostanie uwaga na rozwój, bądź regres, mediów powołanych do istnienia w czasie posługi biskupa Józefa.

\section{Dokonania}

Pierwszą w ogóle decyzją biskupa tarnowskiego w odniesieniu do mediów było powołanie do istnienia wydawnictwa Biblos. Nie była to nowość w skali kraju, ale w odniesieniu do diecezji, w której został ordynariuszem - tak. Jednocześnie był to, według słów ks. dr. Stanisława Budzika, „pierwszy zwiastun nowego stylu działania, który później wiele razy zaskakiwał przyzwyczajonych do znacznie mniejszych obrotów współpracowników: jasna wizja, konkretne środki jej realizacji i szybkość działania"3. Biblos został założony dnia 26 listopada 1990 roku, a już 19 grudnia tego roku otwarto księgarnię wydawnictwa nazwaną Domem Dobrej Książki. Komputery, za pomocą których składano książki w pierwszej połowie 1991 roku, zostały zakupione za pieniądze bp. Józefa Życińskiego - podarował je Biblosowi po sprzedaży swojego mieszkania w Krakowie4.

\footnotetext{
3 S. Budzik, Pierwszy pomysł Biskupa Życińskiego - Wydawnictwo Biblos, „Currenda” nr 6 (1997), s. 30.

4 Tamże, s. 31.
} 
Dla ordynariusza tarnowskiego szczególnie pracowitym w kwestii zakładania mediów był rok 1993, kiedy to rozpoczęły swoją działalność aż trzy podmioty - Katolicka Agencja Informacyjna (10 czerwca), redakcja „Gościa Tarnowskiego” (29 sierpnia) oraz diecezjalna rozgłośnia Radio Dobra Nowina (24 grudnia). Prace przygotowawcze trwały już wcześniej, po kilkanaście miesięcy - chodziło przecież o spore przedsięwzięcia, jak np. KAI. Była ona pierwszą i jedyną w Europie Środkowowschodniej agencją informacyjną obejmującą nie tylko wszystkie diecezje w kraju. Stanowiła ona wówczas jedyny sięgający na wschód - aż do Japonii - tego typu podmiot związany z Kościołem. Katolicka Agencja Informacyjna zainteresowana była zagadnieniami związanymi z religią w całej Polsce oraz Watykanie; korespondenci KAI, w miarę możliwości, pracowali też w pozostałych częściach świata. Często byli to polscy duchowni rozsiani po całym świecie. Siedziba agencji w Warszawie została wyposażona w sprzęt komputerowy dzięki pomocy Konferencji Biskupów Katolickich USA - za pośrednictwem ks. Georga Sarauskasa, z którym kontakt nawiązał bp Józef. System Galacticom ${ }^{5}$, na zasadzie BBS-ów, pozwalał na przesyłanie pakietów depesz dzięki połączeniom modemowym (Internet nie był

\footnotetext{
5 System został wprowadzony w październiku 1996 roku - J. Kloch, Zastosowania najnowszych technologii Web 2.o, w: Media w Kościele i Kościót $w$ mediach. Edukacja medialna, dziennikarska i w zakresie public relations oraz zastosowania Web 2.o w Kościele w Polsce, red. M. Przybysz, J. Kloch, Katowice 2012, s. 57.
} 
wówczas jeszcze powszechnie dostępny). Część pracowników Agencji została przeszkolona w USA, a dla przedstawicieli wszystkich diecezji w Polsce został zorganizowany kurs prowadzony przez specjalistów z IBM ${ }^{6}$. W kolejnych latach redaktor naczelny agencji, Marcin Przeciszowski, w porozumieniu z bp. Życińskim, Pieronkiem i Chrapkiem, wielokrotnie zwoływał robocze spotkania z korespondentami oraz organizował dla nich szkolenia związane z codzienną pracą dziennikarza agencji informacyjnej.

Historia początków założonego przez ordynariusza tarnowskiego kolejnego medium, tj. „Tarnowskiego Gościa Niedzielnego", jest typowym przykładem etapów działań podejmowanych przez niego w zapoczątkowywaniu w diecezji kolejnego środka społecznego przekazu - w tym wypadku tygodnika. Po rozmowach z redaktorem naczelnym ks. Stanisławem Tkoczem (12 czerwca 1993) podjęto kolejne kroki - rozmowy z kandydatem na kierownika zespołu w Tarnowie i jego nominację (23 czerwca 1993), mianowanie kilku księży na korespondentów terenowych,

6 Kurs odbył się w maju 1992 roku w Łaźniewie pod Warszawą J. Kloch, Zastosowania najnowszych technologii Web 2.o, dz. cyt., s. 57. Kontynuując przygotowania do powstania KAI, listem z dnia 1 września 1993 roku bp Tadeusz Pieronek, ówczesny sekretarz generalny KEP, skierowanym do wszystkich biskupów diecezjalnych, zaprosił na spotkanie „przedstawicieli kurii zajmujących się komputerami”. Celem spotkania było przyjęcie jednolitego systemu informatycznego - „przedłożenie propozycji dotyczących programów [komputerowych] i form współpracy z diecezjami" - por. Archiwum Kurii Diecezjalnej w Tarnowie. 
nakreślenie programu i sprecyzowanie oczekiwan' ${ }^{7} \mathrm{w}$ odniesieniu do zespołu redakcyjnego „Gościa” oraz starania o pomieszczenia dla redakcji. Kiedy już mutacja diecezjalna zaczęła się ukazywać (29 sierpnia 1993), ordynariusz tarnowski raz po raz zapraszał do siebie dziennikarzy, a po otwarciu lokalu sam przychodził do redakcji. „Żywo reagował na wszystko. Co się działo na łamach, wykazywał błędy, chwalił udane teksty [...], starał się o zwiększenie

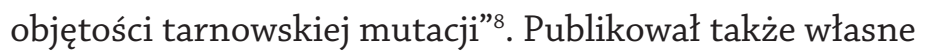
teksty, zawsze pamiętał o życzeniach dla czytelników na Boże Narodzenie i Wielkanoc. Bardzo życzliwie traktował zespół redagujący „Gościa Tarnowskiego”.

Cztery miesiące po ukazaniu się w Tarnowie pierwszego numeru tygodnika, rozpoczęło nadawanie programu diecezjalne Radio Dobra Nowina - już trzecie medium uruchomione w 1993 roku przez bp. Józefa Życińskiego. O ile w wypadku lokalnego „Gościa Niedzielnego” znacznym wsparciem pod wszelkimi względami była redakcja główna w Katowicach, o tyle od podstaw i o własnych siłach trzeba było organizować radio - nowość, jeśli chodzi o diecezje w Polsce. Dotąd, po II wojnie światowej nie było żadnych możliwości prawnych dla Kościoła w Polsce,

7 Wieloletni kierownik oddziału „Gościa Tarnowskiego” ks. Zbigniew Adamek przytoczył w artykule w numerze specjalnym "Currenda” całość owego programu sformułowanego przez biskupa tarnowskiego por. Z. Adamek, Zaproszenie "Gościa”, który stał się domownikiem, „Currenda" nr 6 (1997), s. 25-27.

8 Tamże, s. 25. 
by zakładać własne rozgłośnie9. Dopiero Ustawa z dnia 17 maja 1989 r. o stosunku Państwa do Kościoła katolickiego w Polskiej Rzeczypospolitej Ludowej ${ }^{10}$ określiła, że „Kościół ma prawo do zakładania i używania urządzeń radiotelekomunikacyjnych przeznaczonych do nadawania programów radiofonicznych i telewizyjnych oraz do uzyskiwania na ten cel niezbędnych częstotliwości"1 ${ }^{\text {"11 }}$. Ta możliwość zaczęła być wykorzystywana, co ciekawe, najpierw przez parafie ${ }^{12}$, a następnie diecezje i zgromadzenia zakonne. Pierwsza propozycja (grudzień 1991) zorganizowania na terenie diecezji tarnowskiej niewielkiego radia parafialnego w Nowym Sączu spotkała się z brakiem zgody biskupa. Jak pisze autor pomysłu, ks. Ryszard Piasecki, stało się tak ze względu na „ówczesną krytykę

9 Ostatnia katolicka rozgłośnia radiowa została uruchomiona 8 grudnia 1938 roku w Niepokalanowie. Był to pomysł o. Maksymiliana Kolbe. Stacja „SP 3 Radio Niepokalanów” nadała jedynie kilka audycji próbnych. Do wybuchu II wojny światowej nie doczekała się oficjalnego pozwolenia od władz państwowych na nadawanie. Por. P. Sotowski, Historia uruchomienia Radia Niepokalanów, http://www.radioniepokalanow.pl/o-nas/historia.html [dostęp: 12.06.2016].

10 Dz.U. 1989 Nr 29, poz. 154.

11 Tamże, art. 48 pkt. 1.

12 Pierwszą rozgłośnią, jaka skorzystała z nowego prawa, było radio założone już w listopadzie 1989 roku przez proboszcza wiejskiej parafii Brosza Duża, niemal dokładnie 51 lat po próbach nadawania o. Kolbego w Niepokalanowie - por. L. Dyczewski, Radio Kościoła katolickiego w Polsce: historia, struktura, funkcje, w: I. Hofman, D. Kępa-Figura, Wspótczesne media: status, aksjologia, funkcjonowanie, t. 1, Lublin 2009, s. 280-292; K. Sagan, Historia radiofonii w Polsce, http://old.radiopolska.pl/portal/article.php?story=Prawie_wolny_rynek [dostęp: 13.06.2016]. 
przypadków wykorzystywania tzw. częstotliwości kościelnych i bp Józef Życiński odsunął decyzję na nieco późniejszy czas" ${ }^{\prime \prime}$, ale nie ad calendas graecas. Decyzję pozytywną podjął rok później - w listopadzie 1992 roku, i zlecił prace organizacyjne wspomnianemu wyżej pomysłodawcy, wówczas wikariuszowi w parafii św. Małgorzaty w Nowym Sączu. Uzyskane w 1992 i 1993 roku częstotliwości radiowe dały gwarancję uruchomienia rozgłośni. Fundusze na remont budynku dla redakcji radia oraz na zakup wyposażenia i sprzętu pochodziły „ze środków diecezjalnych, a także pozyskiwanych osobiście przez Księdza Biskupa"14. W Tarnowie nigdy nie istniała żadna rozgłośnia, toteż wielkim wyzwaniem było przeszkolenie zespołu osób do pracy w radiu - od obsługujących stoły mikserskie po redaktorów-prezenterów. Warsztaty dla przyszłych radiowców (listopad-grudzień 1993) wstępnie wyłoniły zespół pracowników etatowych, osób współpracujących z rozgłośnią oraz wolontariuszy. Udoskonalanie umiejętności trwało później wiele lat ${ }^{15}$. Niemniej tarnowskie Radio Dobra Nowina rozpoczęło nadawanie programu 24 grudnia 1993 roku. W ten sposób został uruchomiony w diecezji przez biskupa tarnowskiego Józefa Życińskiego kolejny ze środków społecznego przekazu.

\footnotetext{
13 R. Piasecki, Radio Dobra Nowina - współczesny środek ewangelizacji, „Currenda” nr 6 (1997), s. 69-70.

14 Tamże, s. 70.

15 M. Drożdż, Radio Plus Dobra Nowina. Struktura, program, perspektywy, Warszawa, Tarnów 2006².
} 


\section{Informatyka i Internet}

Po tym, jak w Wigilię Bożego Narodzenia 1993 roku RDN rozpoczęło nadawanie, powstała jeszcze jedna medialna nowość, której początek dał bp Józef Życiński - strona internetowa diecezji tarnowskiej, udostępniona 24 lutego 1997 roku. Należy ją jednak traktować w odniesieniu do mediatyzacji jako ciąg dalszy procesu zapoczątkowanego na przełomie lat osiemdziesiątych i dziewięćdziesiątych ubiegłego wieku. Chodzi o zastosowania informatyki w służbie całej diecezji tarnowskiej oraz Kościoła w Polsce, co nieco wcześniej było analizowane przez grupę duchownych i świeckich. Wydzielenie tych działań z całości dokonań medialnych bp. Józefa Życińskiego jest uzasadnione informatyka i Internet we wspólnocie kościelnej to była zupełna nowoś ć $^{16}$, to przecieranie szlaków, którymi dotąd nikt nie szedł ani w Kościele lokalnym, ani w powszechnym. W przypadkach obydwu dziedzin mowa o pionierskich pracach i rozwiązaniach.

Jeśli chodzi o kwestie informatyczne, to warto zauważyć, że pod koniec lat osiemdziesiątych XX wieku szereg wykładowców z uczelni tarnowskiej zaczęło posługiwać się komputerami sprowadzonymi z USA lub Europy Zachodniej. Podstawowym ich zastosowaniem było przygotowywanie tekstów - wykładów, referatów, artykułów,

16 Por. J. Kloch, E-Kościół? Miejsce informatyki i Internetu w przepowiadaniu, w: „Przekaż mojemu ludowi, co mówi Bóg”. Ewolucja czy kryzys przepowiadania?, red. K. Klauza, M. Wyrostkiewicz, Lublin 2007, s. 113-122. 
książek itp. Pierwszymi posługujących się edytorami tekstów byli ks. prof. Michał Heller, bp Józef Życiński oraz ks. dr Stanisław Budzik. Wykorzystanie rozwiązań informatycznych interesowało nie tylko naukowców, ale i duszpasterzy ${ }^{17}$ oraz pracowników różnych urzędów kościelnych. W jaki sposób technika komputerowa może służyć duchownym w parafiach, w zarządzaniu nieruchomościami diecezji czy w zajmowaniu się finansami? Takie i podobne pytania zadawali sobie analizujący możliwości wprzęgnięcia rozwiązań informatycznych w prace wspólnoty kościelnej ${ }^{18}$.

W diecezji tarnowskiej od jesieni 1988 roku pracowała grupa złożona z duchownych i informatyków; analizowała ona możliwości zastosowań komputerów w misji Kościoła na różnych poziomach. Wiosną 1989 roku przekazali oni abp. Jerzemu Ablewiczowi owoc analiz - opracowanie ukazujące w metodyczny sposób możliwości wykorzystania zdobyczy informatyki w codziennej pracy Kościoła ${ }^{19}$.

${ }^{17}$ J. Kloch, Internet a duszpasterstwo - filozofia umiaru, „Więż” nr 2 (2001), s. 90-101 [artykuł ukazał się także w: M. Robak i in., Zarzućcie sieć. Chrześcijanie wobec wyzwań Internetu, Warszawa 2001, s. 101-116].

${ }_{18}$ W. Iwaniec, J. Kloch, Informatyka w stużbie Kościołowi. Możliwości zastosowania komputerów w kurii diecezjalnej, seminarium duchownym oraz w parafiach, w: Internet i Kościót, red. J. Kloch, Warszawa 2011, s. 140-149; J. Kloch, Zastosowania informatyki w pracy kapłana, czyli po co księdzu komputer?, „Religioni et litteris” 37 (1989) nr 1-3, s. 1-9. Por. także: J. Chrapek, Wobec nowej mentalności. Środki społecznego przekazu „znakiem czasu”, „Mass-Media” nr 1 (1989), s. 5-6.

19 Dokument zredagowali W. Iwaniec i J. Kloch; został on przekazany abp. Jerzemu Ablewiczowi na spotkaniu w dniu 16 kwietnia 1989 
W tekście omówione zostały programy, ich zastosowania oraz dziedziny misji Kościoła, w których mogły być wykorzystywane; przytoczona też została literatura fachowa - także w języku niemieckim. Analogiczne opracowani $e^{20}$ powstało na zlecenie ks. dr. Jana Chrapka, który przewodniczył w pracach II Polskiego Synodu Plenarnego grupie zajmującej się mediami. Kiedy więc bp Józef Życiński - korzystający już od szeregu lat z dobrodziejstw informatyki - przybył jesienią 1990 roku do Tarnowa, zastał tam zespół osób z pomysłami gotowymi do realizacji. W nowym biskupie tarnowskim znaleźli oni sprzymierzeńca i promotora.

Biskup Józef rozpoczął i aktywnie wspierał informatyzowanie urzędów kurii oraz seminarium duchownego. Proces ten zapoczątkowała sesja „Możliwości zastosowań informatyki w wybranych pracach Kościoła”. Odbyła

roku - zob. W. Iwaniec, J. Kloch, Informatyka w stużbie Kościołowi. Możliwości zastosowania komputerów w kurii diecezjalnej, seminarium duchownym oraz $w$ parafiach, dz. cyt.

${ }_{20}$ W. Iwaniec, J. Kloch, Informatyka - Kościołowi. Możliwości wykorzystania zdobyczy informatyki w pracach Kościoła w Polsce. Opracowanie dla V Komisji Synodalnej ds. Środków Społecznego Przekazu, Tarnów 1990 [mps]. Tekst obecnie znajduje się w Sekretariacie Konferencji Episkopatu Polski w Archiwum II Synodu w teczce nr 4 V Komisji Środków Społecznego Przekazu przygotowującej tenże Synod. Przewodniczący Komisji ks. dr Jan Chrapek odnotował na tekście maszynopisu, że materiał został wykorzystany w czasie sympozjum w Otwocku-Świdrze (22-24.02.1990). Interesujące jest to, że autorzy opracowania wśród możliwości zastosowań informatyki w misji Kościoła w 1990 roku wskazali założenie agencji informacyjnej, określając ją mianem Katolicka Agencja Prasowa - Internet i Kościót, dz. cyt., s. 148. 
się ona w tarnowskiej kurii diecezjalnej dnia 21 stycznia $1991 \mathrm{roku}^{21}$. Tydzień później, podczas kursu duszpasterskiego dla duchownych diecezji tarnowskiej, w celu zapewnienia kompatybilności co do wymiany danych, ogłoszono i przyjęto standardy komputerowe dla diecezji tarnowskiej $^{22}$.

Biskup Życiński zadbał o edukację informatyczną w pierwszym rzędzie alumnów i wykładowców seminarium duchownego, ale także pracowników administracyjnych tegoż, jak i kurii diecezjalnejej. Jego plany co do kształcenia informatycznego wspomogło uruchomienie pracownii komputerowej w październiku 1991 roku w Wyższym Seminarium Duchownym w Tarnowie ${ }^{24}$. Była ona pierwszą

${ }^{21}$ Archiwum Kurii Diecezjalnej w Tarnowie.

${ }_{22}$ W. Iwaniec, J. Kloch, Komputerowy standard diecezjalny, „Currenda” 7-9 (1991), s. 531-533.

23 Pierwszy kurs komputerowy odbył się w kurii diecezjalnej w Tarnowie zimą 1991 roku. Przeprowadzili go dr Władysław Iwaniec - informatyk, oraz ks. Józef Kloch.

24 Jej powstanie było możliwe dzięki wsparciu wiernych parafii św. Błażeja w Saarwellingen (diec. trewirska). Pomoc tę zorganizował Alois Paul, urzędnik tamtejszej Kreissparkasse i jednocześnie członek rady parafialnej. Przekazana wówczas suma 10 tys. marek zachodnioniemieckich wystarczyła na zakup 6 komputerów typu IBM AT oraz tyluż drukarek igłowych Star 24-10 (por. J. Życiński, List do Aloisa Paula z dnia 26.11.1991 r., Archiwum Kurii Diecezjalnej w Tarnowie). Na oprogramowanie, oprócz systemu operacyjnego MS DOS, złożyły się anglojęzyczne edytor tekstu WordPerfect 5.1 oraz manager plików Norton Commander. Stosowanie takich właśnie, a nie innych programów wprowadzone zostało na podstawie stosownego zalecenia opublikowanego w „Currendzie” - piśmie urzędowym diecezji tarnowskiej - by zachować kompatybilność danych; por. W. Iwaniec, J. Kloch, Komputerowy standard diecezjalny, dz. cyt. 
w Polsce pracownią komputerową uczelni katolickiej. Służyła nade wszystko alumnom podczas ćwiczeń w ramach studiów ${ }^{25}$, ale także siostrom zakonnym oraz księżom, którzy chcieli poszerzyć swoją wiedzę w tym zakresie ${ }^{26}$. Do zajęć został przygotowany specjalny skrypt ${ }^{27}$.

Kursy komputerowe dla duchownych stały się w diecezji tarnowskiej popularne zwłaszcza od 1992 roku. Wtedy to oddano do użytku pierwszy tego typu w Polsce program „Komputerowa kartoteka parafialna” ${ }^{28}$. Równolegle

25 Od roku akademickiego 1991/92 brali w nich udział obowiązkowo wszyscy klerycy z III roku studiów w ramach zaliczania zajęć z zastosowań informatyki.

${ }^{26}$ W wypadku alumnów ćwiczenia odbywały się przez jeden semestr po dwie godziny tygodniowo. Celem zajęć, które kończyły się zaliczeniem, było zaznajomienie studentów z obsługą komputera w zakresie pozwalającym na samodzielne zredagowanie pracy magisterskiej.

${ }_{27}$ W. Iwaniec, J. Kloch, Przechadzki z komputerem, czyli krok po kroku z wybranymi programami komputerowymi, Tarnów 1991, ss. 150 (Pomoce Naukowe Instytutu Teologicznego w Tarnowie, 2). Analogiczny przedmiot został wprowadzony w innych seminariach duchownych m.in. w rzeszowskim, sosnowieckim i krakowskim. Siedem lat później powstał bliźniaczy skrypt: J. Bajorek i in., Zastosowania informatyki w duszpasterstwie, Rzeszów 1998 [mps i dyskietka z plikami do ćwiczeń].

${ }^{28}$ Ów pionierski program zarządzający bazami danych zawartymi w księgach parafialnych (ochrzczonych, małżeństw, zmarłych itp.) przygotowała toruńska firma „Walor”, dzięki włączeniu się w prace programistyczne pochodzącego z Torunia br. Jacka Dembka CSsR, doktoranta ks. prof. Michała Hellera. Pierwsza wersja programu została poddana testowaniu jesienią 1992 roku. Opracowana też została do programu specjalna instrukcja obsługi w formie 6o-stronnicowej książeczki (J. Kloch, Komputerowa kartoteka parafialna, Tarnów 1992). W ślad za tym pomysłem powstały w późniejszych latach kolejne programy - m.in. „Fara dla 
dr Władysław Iwaniec pracował nad specjalistycznym oprogramowaniem finansowym oraz nad personalnymi bazami danych. Stosowane były one przez pracowników administracji tarnowskiego Wyższego Seminarium Duchownego oraz w kurii diecezjalnej w Tarnowie ${ }^{29}$.

Rozwijająca się sieć internetowa nie ominęła Tarnowa. Rozmowy z przedstawicielami Naukowej i Akademickiej Sieci Komputerowej trwały do jesieni 1995 roku i w ciągu roku zostały uwieńczone uruchomieniem pierwszego w Polsce serwera internetowego na uczelni katolickiej (7 października 1996) 30. Stał się on z czasem sercem ko-

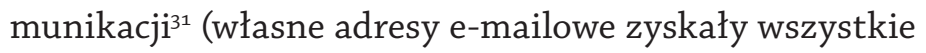
główne urzędy w diecezji oraz wszyscy wykładowcy tarnowskiego seminarium duchownego), za jego pośrednictwem prowadzone były badania w bibliotekach w różnych częściach świata ${ }^{32}$, stanowił też bazę dla strony internetowej diecezji tarnowskiej. Została ona udostępniona

Windows. Zbiór programów wspomagających pracę biura parafialnego" (1996) oraz „Parafia. Program komputerowy do obsługi kancelarii parafialnej i zarządzania parafią" (2003).

29 W. Bergier, W sieci, „Tygodnik Powszechny” nr 15 (1997), s. 4.

30 Serwer został posadowiony w Wyższym Seminarium Duchownym w Tarnowie.

${ }_{31}$ J. Smoleń, Internet jako medium komunikacyjne w Kościele na przykładzie Diecezji Tarnowskiej, „Biuletyn Edukacji Medialnej” 1 (2008), 116128. Por. też: A. Jeż, Jezus Chrystus w kontekście ludzkiej komunikacji, Tarnów 2002.

${ }^{32}$ Por. J. Kloch, W jaki sposób Internet może służyć uczelni katolickiej?, w: Kościót a Europa w dobie wspótczesnej. Sympozjum w 15-lecie Studium Teologii w Wilnie, red. E. Kirstukas, M. Olszewski, Wilno 2010, s. 111-126. 
po niespełna trzech miesiącach pracy, dnia 24 lutego $1997 \mathrm{roku}^{33}$. Dzień wcześniej natomiast oddano do użytku nauczycieli akademickich WSD pracownię komputerową.

Witryna internetowa definitywnie kończy uruchamianie przez bp. Józefa Życińskiego nowych środków społecznego przekazu na terenie diecezji tarnowskiej. Dnia 14 czerwca 1997 roku Jan Paweł II mianuje go arcybiskupem metropolitą lubelskim. W nowej diecezji zastanie on już założone Wydawnictwo „Gaudium”, mutację tygodnika katolickiego „Niedziela” oraz Katolickie Radio Lublin. W seminarium duchownym w roku przybycia abp. Józefa do Lublina nie prowadzono zajęć $\mathrm{z}$ zastosowań informatyki. Natomiast od 13 września 1998 roku z inicjatywy abp. Józefa Życińskiego zaczęto wydawanie „Gościa Lubelskiego” - lokalnej mutacji „Gościa Niedzielnego”.

\section{Proces zmian}

W mediatyzacji Kościoła w Polsce nie bez znaczenia były także historyczne przemiany, jakie następowały w naszym kraju po przełomie politycznym w czerwcu 1989 roku. Powstało nowe prawo, które umożliwiło uruchamianie m.in. rozgłośni diecezjalnych, zakładanie nowych wydawnictw książkowych, poszerzenie działalności istniejących już czasopism, powoływanie do życia agencji

33 Nieco ponad miesiąc później (30.03.1997), pod adresem www.vatican.va została otwarta oficjalna strona Stolicy Apostolskiej. 
informacyjnych, a nawet telewizji. Już nie tyle ze względów prawnych, co z powodu umożliwienia dostępu do sieci i żywiołowego rozwoju coraz to nowych rozwiązań internetowych Kościół zyskał niespotykane dotąd, nowe możliwości w komunikowaniu się ze współczesnym światem oraz w głoszeniu Dobrej Nowiny, na niespotykaną dotąd skalę̧34. Twórca internetowych stron WWW sir Timothy Berners-Lee nawet nie przypuszczał, jak znaczące narzędzie dał całej ludzkości.

Wiele cech witryn internetowych znakomicie służy także właśnie rozprzestrzenianiu przesłania Chrystusa - na WWW można bowiem umieścić dowolne treści dla dowolnego typu komputera, oprogramowania, języka, rodzaju dokumentu i połączenia z Internetem (cechy uniwersalności). Żadne władze nie muszą zezwalać na założenie jakiejkolwiek strony (decentralizacja) ${ }^{35}$. Własności te w 2002 roku skłoniły nawet abp. Johna Foleya do zestawienia atrybutów sieci z cechami Kościoła. Internet może być 1) „nazwany katolickim, ponieważ jest uniwersalny i dociera wszędzie”; 2) „mógłby być nazwany apostolskim, [...] dlatego, że reprezentuje nowy sposób bycia apostołami

34 J. Kloch, Filozofia 3 W, w: I Ogólnopolskie Seminarium „Internet jako narzędzie ewangelizacji”, Warszawa 1998, s. 12-18.

35 Zasadnicze cechy Internetu i WWW za: T. Berners-Lee, Niech nam żyje WWW, „Świat Nauki” nr 1 (2011), s. 56-61. Por. też dwa inne interesujące artykuły na temat przyszłości Sieci: T. Berners-Lee, N. Shadbolt, Traktat o Sieci, „Świat Nauki” nr 11 (2008), s. 70-75 oraz T. Berners-Lee, J. Hendler, O. Lassila, Sieć semantyczna, „Świat Nauki” nr 7 (2001), s. 41-49. 
w sensie misyjnego przekraczania granic”; 3) „w pewnym sensie Internet mógłby być nazwany jednym [...] - w sensie jedności technologicznej" ${ }^{36}$. Ówczesny przewodniczący Papieskiej Rady ds. Środków Społecznego Przekazu świadom był tego, że sieci nie można przypisać czwartej cechy Kościoła - świętości, gdyż „istnieje zbyt dużo problemów i podstępów zła z nim związanych" ${ }^{37}$. Wzywa jednak do ciągłej refleksji i analiz nad sposobami wykorzystania Internetu, określając go jako „doskonałe narzędzie do przekazywania Dobrej Nowiny Jezusa Chrystusa" ${ }^{38}$.

Z kolei bp Życiński kładł nacisk na edukację informatyczno-internetową i miał swój wkład w tej dziedzinie nie tylko w diecezjach, którymi kierował, ale na poziomie Kościoła powszechnego ${ }^{39}$. Ordynariusz diecezji tarnowskiej

36 J. Foley, Internet - wyzwanie naszych czasów, w: Internet i Kościót, dz. cyt., s. 212-213.

37 Tamże, s. 213.

38 Tamże, s. 212. Potrzebę nieustannej wręcz refleksji nad coraz to nowymi możliwościami, jakie daje Sieć, wskazują papieże od Jana Pawła II do Franciszka włącznie, zwłaszcza w corocznych orędziach na Dzień Środków Społecznego Przekazu. Całość nauczania na ten temat (19902011) zgromadzona jest w monografii Internet $i$ Kościót, dz. cyt. s. 16-137. Najnowsze dokumenty (od 2012 roku) publikuje portal Paulus: http:// www.paulus.org.pl/210,oredzia-na-dni-srodkow-spolecznego-przekazu [dostęp: 12.06.2016].

39 J. Życiński, Internet i formacja w seminariach duchownych. Wystapienie w czasie zgromadzenia plenarnego Kongregacji Edukacji Katolickiej, w: Internet i Kościót, dz. cyt., s. 240. W tym duchu nauczał także następca Jana Pawła II - por. Benedykt XVI, Kapłan i duszpasterstwo w świecie cyfrowym: nowe media w służbie Słowa; tenże, Nowe technologie komunikacyjne i głoszenie Ewangelii; tenże, Rola Internetu w formacji seminaryjnej. Przemówie- 
wiedział, że nie wystarczy tylko zakupić sprzęt komputerowy. Wstępnych analiz co do sposobów jego wykorzystania w danej instytucji dokonywał wspólnie ze współpracownikami, pozostawiając szczegóły specjalistom. Tworzył grupy robocze, które nie tylko je opracowywały, ale miały na względzie edukowanie przyszłych użytkowników rozwiązań informatycznych. Wyczuwał, że zbyt uproszczony jest pogląd, wedle którego przepaść cyfrowa ${ }^{40}$ polega jedynie na podziale na tych, którzy nie mają komputerów i nie posiadają do nich dostępu, i na tych, którzy je mają i posiadają dostęp do nich oraz do oprogramowania i Internetu. Tak też sądzili później m.in. Mark Warschauer i inni zajmujący się tym zagadnieniem. W problemie digital divide chodzi również o zastosowania komputerowego hardware i software w konkretnych sytuacjach i przygotowanie użytkowników do korzystania z rozwiązań informatycznych. Biskup Józef intuicyjnie to wyczuwał już na początku lat dziewięćdziesiątych XX wieku i nie był zwolennikiem tzw. technologicznego

nie z okazji zgromadzenia plenarnego Kongregacji Edukacji Katolickiej; dokumenty Benedykta XVI zawarte są w zbiorze Internet i Kościót, dz. cyt., s. 82-98.

${ }^{40}$ Ang. digital divide; określenie to ukuła w połowie lat 9o. XX wieku amerykańska Krajowa Administracja Telekomunikacji i Informacji (NTIA) będąca ciałem doradczym prezydenta USA ws. telekomunikacji i polityki informacyjnej. Termin ten przyjął się powszechnie na całym świecie; w języku polskim zwykle jest oddawany wyrażeniem przepaść cyfrowa, ale także jako wykluczenie cyfrowe, luka cyfrowa czy podział informacyjny - por. M. Warschauer, Cyfrowy podziat, „Świat Nauki" 9 (2003), s. 47 - przypis redakcji odnośnie do różnych przekładów określenia digital divide. 
determinizmu, tj. „wiary, że samo posiadanie lub dostęp do urządzeń sprawi, że zostaną one właściwie i zgodnie z przeznaczeniem wykorzystane, przynosząc pożądane zmiany społeczne"41. Dlatego wprowadzenie rozwiązań informatycznych do administracji kurii diecezjalnej czy seminarium duchownego było zawsze poprzedzone badaniami oraz kursami komputerowymi. W kręgach akademickich tego typu podejście określane jest jako informatyka społeczna (ang. social informatics). Oprócz odpowiedniego wyposażenia należy zadbać nade wszystko o kształcenie w zakresie dobrego wykorzystania oprogramowania oraz o grupę specjalistów-liderów, którzy nadawać będą kierunek zastosowaniom rozwiązań w różnych dziedzinach ${ }^{42}$.

Dzieło biskupa tarnowskiego w zakresie edukowania alumnów zostało podjęte m.in. przez wykładowców Instytutu Edukacji Medialnej i Dziennikarstwa. O edukację medialną apelował ks. prof. Antoni Lewek, założyciel tegoż Instytutu ${ }^{43}$. Profesor UKSW Monika Marta Przybysz w swojej pracy habilitacyjnej mocno podkreśliła konieczność wprowadzenia specjalnego przedmiotu tego typu we wszystkich seminariach duchownych w Polsce ${ }^{44}$. Zaznacza

41 M. Warschauer, Cyfrowy podział, art. cyt., s. 44.

42 Por. tamże, s. 44-45.

43 W 2010 roku za Janem Pawłem II pisał o potrzebie edukacji medialnej - por. A. Lewek, Kościół a mediokracja w Polsce, „Kultura - Media Teologia" nr 2 (2010) 2, s. 26.

44 M. M. Przybysz, Rzecznictwo prasowe winstytucjach kościelnych w Polsce w kontekście mediów społecznościowych, Kielce 2013, s. 343-345. 
ona, że kształcenie w tym zakresie alumnów może „zachęcić ich do docierania do internautów, których jeszcze nie ma w Kościele, bądź już ich nie ma" ${ }^{45}$, a poza tym wyedukować „profesjonalnych apostołów-rzeczników eklezjalnych korzystających z dostępnych metod, narzędzi i sposobów głoszenia Ewangelii współczesnemu człowiekowi w kontekście mediów społecznościowych" ${ }^{46}$. Sugeruje ona także, by edukacja medialna w seminariach duchownych nie ograniczała się tylko do alfabetyzacji internetowej, ale obejmowała również elementy public relations oraz zagadnienia, jak wykorzystać media w swojej pracy duszpasterskiej ${ }^{47}$. W obecnie obowiązującym w Polsce ratio studiorum co prawda jest przedmiot „środki społecznej komunikacji”, jednak są to zajęcia fakultatywne, a ich program nie został określony - zauważa Monika Przybysz ${ }^{48}$. Biskup Józef Życiński natomiast podkreśla, że ogólnokościelny program studiów dla wyższych seminariów duchownych został podpisany przez Pawła VI, a od tego czasu „upadł

45 Tamże, s. 344.

46 Tamże.

47 Na ten temat odbyła się 15 maja 2014 roku konferencja naukowa na Uniwersytecie Kardynała Stefana Wyszyńskiego w Warszawie pt. „Edukacja medialna w seminariach duchownych i instytutach teologicznych w Polsce"; por. J. Kloch, M. Przybysz, Edukacja medialna w seminariach duchownych. Dylematy i propozycje, w: Człowiek. Media. Edukacja, red. J. Morbitzer, E. Musiał, Kraków 2012, s. 212-225. Patrz także: A. Domaszk, Internet dobrodziejstwem i zagrożeniem: formacyjne wyzwania dla seminariów duchownych, „Seminare” nr 33 (2013), s. 63-79.

$4^{8}$ M. M. Przybysz, Rzecznictwo prasowe w instytucjach kościelnych w Polsce w kontekście mediów społecznościowych, dz. cyt., s. 345. 
mur berliński, w kulturze zaczął dominować Internet"49. Z tego powodu zarówno biskup, jak i inni członkowie Kongregacji ds. Wychowania Katolickiego postulowali dwa rozwiązania - „albo w istotny sposób opracować nowe zasady ratio studiorum, albo całkowicie je zmienić" ${ }^{\circ}$.

\section{Wnioski końcowe}

Należy podkreślić trwałość procesów mediatyzacji w Kościele w Polsce, których bp Józef Życiński był promotorem. Do czasów współczesnych istnieją wszystkie podmioty medialne powołane do życia przez ordynariusza tarnowskiego (i lubelskiego) lub przy jego współudziale. W skali ogólnopolskiej jest to stale rozwijająca się Katolicka Agencja Informacyjna. Na terenie diecezji tarnowskiej RDN Małopolska i RDN Nowy Sącz są kontynuatorami Radia Dobra Nowina. Nadal z powodzeniem działa wydawnictwo Biblos oraz mutacja „Gościa Niedzielnego”. Podobnie strony WWW diecezji ${ }^{51}$ ( $z$ wieloma nowymi, które są redagowane

49 J. Życiński, O obradach Kongregacji ds. Wychowania Katolickiego, depesza Katolickiej Agencji Informacyjnej z dnia 24 stycznia 2008 roku (dostępna tylko dla abonentów).

50 Tamże.

51 Witryna internetowa diecezji tarnowskiej utrzymuje się w czołówce wśród religijnych stron WWW w Polsce - A. Garapich, Witryny internetowe o tematyce religijnej, w: Internet $i$ Kościót, dz. cyt., s. 261-263. Podobnie jeśli chodzi o liczbę parafii posiadających własny adres mailowy oraz stronę internetową - Instytut Statystyki Kościoła Katolickiego SAC, Strony internetowe i adresy e-mail parafii w Polsce, w: Internet i Kościół, dz. cyt., s. $256-257$. 
przez podmioty diecezjalne); ćwiczenia z zastosowań informatyki zostały przekształcone w konwersatorium, a używanie komputerów w administracji urzędów diecezjalnych jest powszechne i oczywiste.

Jednocześnie trzeba zauważyć, że na początku lat dziewięćdziesiątych ubiegłego wieku wprzęgnięcie wielu mediów w służbę głoszenia Dobrej Nowiny nie było ani codziennością, ani czymś oczywistym. Promotorem wszystkich wymienionych tu przedsięwzięć był bp Józef Życiński; z zapoczątkowaniem ich uporał się wraz ze współpracownikami w niespełna trzy lata - tyle czasu minęło od założenia 1 grudnia 1990 roku wydawnictwa Biblos do uruchomienia Radia Dobra Nowina 24 grudnia 1993 roku. Dziś ten proces określa się mianem mediatyzacji ${ }^{52}$. Biskup tarnowski był niewątpliwie jej promotorem w Kościele w Polsce. Nie pozostawiał nigdy bez pomocy powołanych przez siebie podmiotów medialnych, sam włączał się w ich prace.

Jednego środka społecznego przekazu nie założył ani w Tarnowie, ani w Lublinie - telewizji, choć często udzielał się w TVP czy prywatnych stacjach telewizyjnych. Nie zainicjował też powołania ogólnopolskiej telewizji katolickiej. Miał w tym wypadku poczucie ogromnych kosztów takiego przedsięwzięcia, a w kontekście powstającej TV Trwam uważał za bezcelowe powoływanie jeszcze

52 Por. też S. Hjarvard, Three Forms of Mediatized Religion. Changing the Public Face of Religion, w: Mediatization and Religion. Nordic Perspectives, red. S. Hjarvard, M. Lövheim, Göteborg 2012, s. 21-44. 
jednego ośrodka telewizyjnego i z tego powodu nie sięgnął po ten środek społecznego przekazu; popierał jednak wielokrotnie podczas zebrań plenarnych Konferencji Episkopatu Polski telewizje związane ze środowiskiem wiernych świeckich (np. TV Familijną czy TV Religię) ${ }^{53}$.

Biskup Józef Życiński w Kościele w Polsce był współzałożycielem Katolickiej Agencji Informacyjnej - co stanowiło nowość w skali wszystkich państw byłego bloku wschodniego. W diecezji tarnowskiej powołał do istnienia wydawnictwo Biblos, Radio Dobra Nowina oraz zapoczątkował wydawanie w Tarnowie mutacji „Gościa Niedzielnego". Za czasów jego posługi założona została pracownia komputerowa, zainicjowano ćwiczenia z zastosowań informatyki oraz powstała strona internetowa diecezji tarnowskiej. W archidiecezji lubelskiej w 1997 roku zastał analogiczne instytucje medialne ${ }^{54}$ - wspierał ich prace i przyczynił się do ich rozwoju. Nie pozostawiał nigdy bez pomocy powołanych przez siebie podmiotów medialnych, sam włączał się w ich działania.

Wydawnictwa i mutacje „Gościa Niedzielnego” już istniały w wielu diecezjach. Podobnie rozgłośnia diecezjal-

53 Opinie takie wyrażał wielokrotnie w czasie zebrań plenarnych Konferencji Episkopatu Polski (informacje własne Autora artykułu, który w latach 2003-2015 pełnił funkcję rzecznika KEP).

54 Wydawnictwo Diecezji Lubelskiej „Gaudium”, mutację tygodnika katolickiego „Niedziela” oraz Katolickie Radio Lublin (w lubelskim WSD w 1997 roku nie były prowadzone zajęcia z zastosowań informatyki). Od 13 września 1998 roku z inicjatywy abp. Józefa Życińskiego zaczął być wydawany także „Gość Lubelski” - lokalna mutacja „Gościa Niedzielnego”. 
na - istniało ich już kilka, choć w Kościele w Polsce były nową możliwością. Natomiast zupełną nowością była informatyzacja wraz z edukacją komputerową̧5, a następnie wprzęgnięcie Internetu w prace Kościoła oraz założenie agencji informacyjnej. Biskup tarnowski wraz ze współpracownikami w ostatnim dziesięcioleciu XX wieku poszedł zupełnie nowymi, nieprzetartymi dotąd we wspólnocie kościelnej szlakami ${ }^{56}$. Analizy ex post wykazują w tym zakresie równoległe i niezależnie od siebie prowadzone pionierskie prace zarówno w Watykanie ${ }^{57}$, jak i w Polsce - w tym wypadku głównie w diecezji tarnowskiej $^{58}$. Ze strony Stolicy Apostolskiej swego rodzaju mo-

55 J. Kloch, Kościół w Polsce wobec Web 2.0, Kielce 2013, s. 209-210.

${ }^{56}$ Przegląd dokonań duchownych i wiernych świeckich w tym zakresie ukazują artykuły i książki, których spis bibliograficzny zawarty jest w dwóch uzupełniających się artykułach: J. Kloch, Kościół - Informatyka-Internet. Wybór bibliografii polskiej z lat 2002-2011, w: Internet i Kościół, dz. cyt., s. 282-297 oraz J. Kloch, Kościót - Internet. Wybór bibliografii polskiej z lat 1991-2002, w: Internet i nowe technologie - ku społeczeństwu przyszłości, red. T. Zasępa, R. Chmura, Częstochowa 2003, s. 67-85.

57 L. Soberon, RIIAL - Information Network of the Church in Latin America, w: Religious Internet Communication. Facts, Trends and Experiences in the Catholic Church, red. D. Arasa, L. Cantoni, A. Ruiz, Roma 2010, s. 154-16o; J.L. Ysern de Arce, Podstawowe elementy informatyki i nowych technologii środków społecznego przekazu w kontekście wyzwań duszpasterskich. Wykład do uczestników II Spotkania Kontynentalnego RIIAL, w: Internet i Kościół, dz. cyt., s. 155-171; J.P. Foley, Sieć informatyczna Kościoła [w Ameryce Eacińskiej] - tożsamość $i$ wyzwania. Wystapienie do uczestników II Spotkania Kontynentalnego RIIAL, w: Internet i Kościót, dz. cyt., s. 151-153.

${ }^{8}$ J. Kloch, Zastosowania najnowszych technologii Web 2.o, dz. cyt., s. 5558; J. Kloch, Kościół w Polsce wobec Web 2.o, dz. cyt., s. 15-16, 209-210, 249. 
delem, na którym testowane były rozwiązania informatyczne i internetowe, była sieć RIIAL (Red Informática de la Iglesia en América Latina - Sieć Informatyczna Kościoła w Ameryce Łacińskiej). Została ona zbudowana z funduszy Watykanu i Konferencji Biskupów Włoch dla Kościoła w Ameryce Południowej i Środkowej. Owocem prac związanych z RIIAL było znalezienie szeregu zastosowań Internetu w Kościele powszechnym w odniesieniu do dystrybucji korespondencji, rozpowszechniania kościelnych dokumentów oraz budowania serwisów informacyjnych. Analogiczne przedsięwzięcia w skali Polski czy diecezji tarnowskiej były podejmowane przez zespoły z udziałem bp. Józefa Życińskiego. Przykładem równoległości myślenia i wniosków, do jakich dochodziły grupy włoska i polska niech będzie czasowa zbieżność uruchomienia stron internetowych - watykańskiej (30 marca 1997) i diecezji tarnowskiej (nieco ponad miesiąc wcześniej - 24 lutego 1997). Owa paralelność analiz oraz pionierskie zastosowania Internetu to bodaj najbardziej znaczące elementy w mediatyzacji Kościoła przełomu wieków, której bp Józef Życiński był promotorem ${ }^{59}$.

59 Osobnym zagadnieniem, stanowiącym jeden $z$ aspektów mediatyzacji, jest znaczna aktywność abp. Józefa Życińskiego w różnego typu mediach, niezależnych jako instytucje od Kościoła i niestanowiących jego części, posługujących się własną polityką działania. 


\section{Chronologia prac związanych z mediatyzacją \\ Kościoła w Polsce - przy współudziale \\ bp. Józefa Życińskiego ${ }^{60}$}

16.04.1989

Przekazanie abp. Jerzemu Ablewiczowi opracowania „Informatyka w służbie Kościołowi”; jego autorami byli dr Władysław Iwaniec i ks. mgr Józef Kloch. Konsultantami byli ks. dr Stanisław Budzik, o. Jacek Dembek CSRS, ks. Ryszard Piasecki, ks. Jan Pikul oraz Mieczysław Witecki.

\subsubsection{0}

Powierzenie ks. dr. Janowi Chrapkowi, przewodniczącemu V Komisji Synodalnej (ds. Środków Społecznego Przekazu) II Synodu Plenarnego w Polsce, opracowania „Informatyka - Kościołowi. Możliwości wykorzystania zdobyczy informatyki w pracach Kościoła w Polsce”. Tekst zredagowali dr Władysław Iwaniec i ks. mgr Józef Kloch.

60 Dwa pierwsze fakty z chronologii miały miejsce przed rozpoczęciem posługi biskupiej Józefa Życińskiego w diecezji tarnowskiej. Zostały tu jednak przywołane, bowiem stanowią część prac analitycznych kontynuowanych po ingresie nowego biskupa tarnowskiego, a dotyczących zastosowań informatyki w misji Kościoła. Ostatnie z wydarzeń - wykład habilitacyjny - jest swego rodzaju zwieńczeniem prac analitycznych w odniesieniu do Internetu w środowisku tarnowskim do czerwca 1997 roku. Wówczas biskup tarnowski został mianowany arcybiskupem metropolitą lubelskim. 


\subsubsection{0}

Założenie Wydawnictwa Diecezji Tarnowskiej „Biblos”; ks. dr Stanisław Budzik zostaje jego dyrektorem.

21.01.1991

Sesja w tarnowskiej kurii diecezjalnej: „Możliwości zastosowań informatyki w wybranych pracach Kościoła”.

28.01.1991

Kurs duszpasterski dla duchownych diecezji tarnowskiej: ogłoszenie diecezjalnych standardów komputerowych (opublikowane zostaną w „Currendzie” - piśmie urzędowym).

1.10 .1991

Wprowadzenie przedmiotu „Wybrane elementy zastosowań informatyki" do programu studiów w Wyższym Seminarium Duchownym w Tarnowie; uruchomienie pierwszej w Polsce pracowni komputerowej na uczelni katolickiej.

3.03.1991

Opublikowanie w wydawnictwie Biblos, w serii pomocy naukowych Instytutu Teologicznego w Tarnowie, pierwszego na uczelni katolickiej w Polsce podręcznika Przechadzki z komputerem, czyli krok po kroku z wybranymi programami komputerowymi. Jego autorami byli Władysław Iwaniec i ks. Józef Kloch. 
10.06.1993

Rozpoczęcie działalności przez Katolicką Agencję Informacyjną; jej redaktorem naczelnym zostaje Marcin Przeciszewski.

29.08.1993

Ukazuje się pierwszy numer „Gościa Tarnowskiego” - mutacji diecezjalnej „Gościa Niedzielnego”; kierownikiem redakcji był mianowany ks. Zbigniew Adamek.

24.12.1993

Rozpoczęcie nadawania programu przez diecezjalną rozgłośnię Radio Dobra Nowina; jego pomysłodawca, ks. Ryszard Piasecki, zostaje dyrektorem administracyjnym RDN.

7.10.1996

Uruchomienie we współpracy z NASK pierwszego w Polsce serwera internetowego na uczelni katolickiej - w tarnowskim Wyższym Seminarium Duchownym.

23.02.1997

Oddanie do użytku pracowni komputerowej dla wykładowców Wyższego Seminarium Duchownego w Tarnowie.

24.02.1997

Udostępnienie strony internetowej diecezji tarnowskiej pod adresem www.diecezja.tarnow.pl; zaprojektował ją i został jej administratorem Jerzy Wiatr. 
26.05.1997

Wykład ks. dr. Stanisława Budzika „Internet a rzeczywistość wirtualna” na jego kolokwium habilitacyjnym na Wydziale Teologicznym Papieskiej Akademii Teologicznej w Krakowie.

Media - Kultura - Dialog. W piąta rocznicę śmierci arcybiskupa Józefa Życińskiego, red. ks. R. Nęcek, ks. W. Misztal, Kraków 2017, s. 199-227.

DOI: http://dx.doi.org/10.15633/9788374385848.17 